\title{
Impact of Eco-Efficient Energy on Sustainable Development in South Asia: Empirical Estimations
}

Praveen Saldanha* and G. S. Premakumara

Assistant Professor, Department of Economics, St. Philomena's College, Mysuru, India Assistant Professor, Department of Economics, University of Mysore, Mysuru, India

\begin{abstract}
Energy is a prerequisite for all production processes and development. However, eco-efficient, sustainable green energy is essential for sustainable development and green growth. The commitments to produce renewable, clean and green energy have compelled all countries, by the International Agreements and Treaties on energy, environmental protection and sustainable growth. In this background, the present work tried to examine the efforts made by South Asian countries in order to produce eco-efficient, sustainable, clean energy and its interactions with economic development. The present study has used secondary time series data on green energy parameters and parameters related to economic development. The econometric techniques such as stationarity, impact models have been used for examination and analysis of data. It has been found from the analysis that energy intensity has been significantly increased in South Asia along with economic development. However, the production of green energy is not commensurate with its expected rate. Moreover, the shares of both renewable energy and renewable electricity in total energy have been declined over the period of time. This is a negative sign of sustainable development and green growth. Hence, there is a need to restructure the energy policy by South Asian countries according to the needs of sustainable development and green growth. Accordingly, consumption, transmission, process, etc., should be made mandatory to use green energy in their total energy consumption. Pigouvian principle of taxing on increasing social cost and subsidization for increasing social benefits is more appropriate for South Asian policies and strategies for eco efficient green energy and green growth.
\end{abstract}

Keywords: Eco-Efficiency, Energy, Sustainable Development, Renewable Energy, Clean Energy and Green Growth

\section{Introduction}

There is a need of stable energy security in a country to have sustainable balanced economic development. Since the concept of energy security is more complex, multidimensional, and contextual, most of the previous studies have tried to define the concept of energy security (Bohi \& Toman, 1996) (Baldwin, 1997). Recent studies have tried to estimate and forecast the energy security (Kamonphorn \& Hironobu, 2014) (Ito, Zhidong \& Komiyama, 2005). Few studies have also tried to develop the dimensions and indicators to measure the energy security (Lixia \& Youngho, 2014). However, there are no unique studies to specifically estimate the impact of ecoefficient, sustainable, clean energy on economic development and present study is a step forward in this direction.

Energy is a prerequisite for all production processes and development. However, eco-efficient, sustainable green energy is critical for sustainable development and green growth. The commitments to produce renewable,

*Email: praveensaldanha.fx@gmail.com 
clean and green energy have compelled all countries, by the International Agreements and Treaties on energy, environmental protection and sustainable growth (Premakumara, 2012). In this background, the present work tried to examine the efforts made by South Asian countries in order to produce eco-efficient, sustainable, clean energy and its interactions with economic development (Lubell, 1961), (Hancock \& Vivoda, 2014).

\section{Review of Literature}

Most of the previous studies have addressed the linkages between energy and development (Masih A. M., 1996) (Asafu-Adjaye, 2000). Some of them have proved the relationship and some of the not proved the relationship between energy and development. (Cheng, 1995) (Yu E. J., 1992). It has been also proved that energy is essential for development, whereas, eco-efficient and clean energy is critical for sustainable development. Adequate and reliable and affordable energy is the pre-requisite for development (Premakumara, 2012). Another important dimension argues that there has been significant association between energy efficiency and development (Sascha \& Andreas, 2015) (Sreenivas, 2014). Most of the early literatures on causation of economic growth on energy consumption have confirmed the causation by using uni-directional Granger- causality Tests (Yu E., 1984) (Kraft J. K., 1978) (Lin, 2003) (Soytas, 2003) (Mozumdar, 2007). During late 90's the economists like Nachane and others have employed Engel-Granger Models to estimate the causation of electricity and energy on economic growth (Nachane, 1988) (Masih, 1996) (Glasure, 1997) (Asafu-Adjaye, 2000) (Thoma, 2004) (Hansen, 2002) (Yoo, 2005). Meanwhile, the co-integration techniques were also used to estimate long-run relationship between energy consumption and economic growth. Jumbe and Huang have proved bi-directional relationship between energy consumption and economic growth (Jumbe, 2004) (Huang, 2008). Estimation of multi-dimensional relationship has also proved the role of energy in overall economic development (Tamizan, 2009) (Shahbaz, 2012). Recently, Sadorsky has proved the influence of financial development on energy consumption (Sadorsky, 2010). Very recently, ARDL bounds test was used to prove the causation of energy demand on export (shahbaz, 2013). But estimating the impact of efficient, clean, sustainable and green energy together on development have not done by any of the previous studies. Therefore, the present study is unique in its approaches and methodology.

\section{Methodology}

The present study has used secondary time series data from 1991 to 2012 on green energy parameters and parameters related to economic development. The econometric techniques such as stationarity, impact models, have been used for examination and analysis of data. The following South Asian Nations have been selected for analysis.

- Bangladesh (BGD).

- Nepal (NEP).

- Indonesia (IDN).

- India (IND).

- Sri Lanka (LKA).

- Pakistan (PAK).

The time series data have been checked for stationarity and then used for further analysis. The Phillip Perron (PP) tests have conducted to check the stationarity of time series data. Econometric models have used to examine the impact of sustainable green and clean energy efficiency parameters on development.

Sustainable green and clean energy efficiency represented by;

- Energy efficiency measured by energy intensity of GDP.

- Clean energy measured by renewable electricity share in total energy output.

- Sustainable energy measured by renewable energy share.

- Green energy measured by $\mathbf{C o 2}$ emission.

- Development measured by GDP of the country.

The model used for the impact analysis is given below;

Log of GDP $=\mathrm{f}($ Energy Intensity + Renewable

Energy + Renewable Electricity $\left.+\mathrm{Co}_{2}\right)+\mathrm{e}$ 
$\Delta \operatorname{lngdp}=\alpha+\beta_{1} \mathrm{EI}+\beta_{2} \mathrm{REL}+\beta_{3} \mathrm{REN}+\beta_{4} \mathrm{Co}_{2}+\mathrm{e}$

Where;

$\Delta$ Ingdp= First Difference of Log of GDP,

$\mathbf{E I}=$ Energy Intensity,

REL $=$ Renewable Electricity Output,

REN $=$ Renewable Energy,

$\mathbf{C o}_{2}=\mathrm{Co} 2$ Emission to the system

$\boldsymbol{\beta}$ 's $=$ Elasticity Coefficients for Independent

Variables,

$\boldsymbol{\alpha}=$ Constant of the Model, and

$\mathbf{e}=$ Error Term for the Model.

\subsection{Phillip-Perron (PP) Tests for Stationarity of Data}

PP tests for level and difference data have been conducted to test the stationarity of data. The tests were conducted for level and difference data with the different models; without drift and trend, with drift and without trend, and with drift and trend.

The PP (Phillip-Perron) test was conducted to find the stationarity of data for data. The test was conducted with three types of models;

1. without intercept and trend $\left(\Delta \mathrm{y}_{\mathrm{t}}=\mathrm{y}_{\mathrm{t}-1}+\mathrm{e}_{\mathrm{t}}\right)$.

2. with intercept $\left(\Delta y_{t}=\alpha+y_{t-1}+e_{t}\right)$.

3. with intercept and trend $\left(\Delta \mathrm{y}_{\mathrm{t}}=\alpha+\mathrm{y}_{\mathrm{t}-1}+\mathrm{T}+\mathrm{e}_{\mathrm{t}}\right)$.

In the following section, PP test was conducted with level, first and second difference data. The test results for level, first and second difference data are presented below;

Table 1. Stationary test for selected variables of Bangladesh

\begin{tabular}{|c|c|c|c|}
\hline BGD & t-value & Significance & Model \\
\hline $\mathrm{CO}_{2}$ & -4.843 & 0.004 & 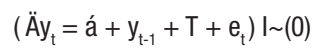 \\
\hline Energy Intensity & -3.664 & 0.000 & $\left(\ddot{A} y_{t}=y_{t-1}+e_{t}\right) I \sim(0)$ \\
\hline Log of GDP & -4.035 & 0.025 & $\left(\ddot{A} y_{t}=a ́ a y_{t-1}+T+e_{t}\right) \mid \sim(1)$ \\
\hline $\begin{array}{c}\text { Renewable } \\
\text { Electricity }\end{array}$ & -2.729 & 0.008 & $\left.\left(\ddot{A} y_{t}=y_{t-1}+e_{t}\right)\right) \sim(0)$ \\
\hline Renewable Energy & -6.587 & 0.000 & $\left(\ddot{A} y_{t}=y_{t-1}+e_{t}\right) \sim(0)$ \\
\hline
\end{tabular}

http://www.informaticsjournals.com/index.php/sdmimd | Vol 8 | Issue 1 | March 2017
Table 2. Stationary test for selected variables of Nepal

\begin{tabular}{cccc}
\hline NEP & t-value & Significance & Model \\
\hline $\mathrm{CO}_{2}$ & -4.306 & 0.013 & $\left(\ddot{\mathrm{A}} \mathrm{y}_{\mathrm{t}}=\mathrm{a}+\mathrm{y}_{\mathrm{t}-1}+\mathrm{T}+\mathrm{e}_{\mathrm{t}}\right) I \sim(0)$ \\
Energy Intensity & -4.307 & 0.000 & $\left(\ddot{\mathrm{A}} \mathrm{y}_{\mathrm{t}}=\mathrm{y}_{\mathrm{t}-1}+\mathrm{e}_{\mathrm{t}}\right) I \sim(0)$ \\
$\begin{array}{c}\text { Log of GDP } \\
\begin{array}{c}\text { Renewable } \\
\text { Electricity }\end{array}\end{array}$ & -4.903 & 0.001 & $\left(\ddot{\mathrm{A}} \mathrm{y}_{\mathrm{t}}=\mathrm{a}+\mathrm{y}_{\mathrm{t}-1}+\mathrm{e}_{\mathrm{t}}\right) \sim(1)$ \\
$\begin{array}{c}\text { Renewable Energy } \\
\text { R }\end{array}$ & -3.765 & 0.000 & $\left(\ddot{\mathrm{A}} \mathrm{y}_{\mathrm{t}}=\mathrm{y}_{\mathrm{t}-1}+\mathrm{e}_{\mathrm{t}}\right) I \sim(1)$ \\
\hline
\end{tabular}

Table 3. Stationary test for selected variables of Indonesia

\begin{tabular}{cccc}
\hline IND0 & t-value & Significance & Model \\
\hline $\mathrm{Co}_{2}$ & -4.322 & 0.013 & $\left(\ddot{\mathrm{A}} \mathrm{y}_{\mathrm{t}}=\mathrm{a}+\mathrm{y}_{\mathrm{t}-1}+\mathrm{T}+\mathrm{e}_{\mathrm{t}}\right) \mid \sim(0)$ \\
Energy Intensity & -2.816 & 0.007 & $\left(\ddot{\mathrm{A}} \mathrm{y}_{\mathrm{t}}=\mathrm{y}_{\mathrm{t}-1}+\mathrm{e}_{\mathrm{t}}\right) \mid \sim(1)$ \\
Log of GDP & -1.999 & 0.046 & $\left(\ddot{\mathrm{A}} \mathrm{y}_{\mathrm{t}}=\mathrm{y}_{\mathrm{t}-1}+\mathrm{e}_{\mathrm{t}}\right) \mid \sim(1)$ \\
$\begin{array}{c}\text { Renewable } \\
\text { Electricity }\end{array}$ & -1.973 & 0.048 & $\left(\ddot{\mathrm{A}} \mathrm{y}_{\mathrm{t}}=\mathrm{y}_{\mathrm{t}-1}+\mathrm{e}_{\mathrm{t}}\right) \mid \sim(0)$ \\
$\begin{array}{c}\text { Renewable Energy } \\
\text { Rener }\end{array}$ & -4.518 & 0.000 & $\left(\ddot{\mathrm{A}} \mathrm{y}_{\mathrm{t}}=\mathrm{y}_{\mathrm{t}-1}+\mathrm{e}_{\mathrm{t}}\right) \mid \sim(0)$ \\
\hline
\end{tabular}

Table 4. Stationary test for selected variables of India

\begin{tabular}{|c|c|c|c|}
\hline IND & t-value & Significance & Model \\
\hline $\mathrm{CO}_{2}$ & -4.095 & 0.000 & $\left(\ddot{A} y_{t}=y_{t-1}+e_{t}\right) I \sim(1)$ \\
\hline Energy Intensity & -10.488 & 0.000 & $\left(\ddot{\mathrm{A}} \mathrm{y}_{\mathrm{t}}=\mathrm{y}_{\mathrm{t}-1}+\mathrm{e}_{\mathrm{t}}\right) I \sim(0)$ \\
\hline Log of GDP & -3.499 & 0.019 & $\left(\ddot{A} y_{t}=a ́+y_{t-1}+e_{t}\right) I \sim(0)$ \\
\hline $\begin{array}{l}\text { Renewable } \\
\text { Electricity }\end{array}$ & -3.962 & 0.000 & $\left(\ddot{A} y_{t}=y_{t-1}+e_{t}\right) l \sim(1)$ \\
\hline Renewable Energy & -3.628 & 0.001 & $\left(\ddot{A} y_{t}=y_{t-1}+e_{t}\right) I \sim(0)$ \\
\hline
\end{tabular}

Table 5. Stationary test for selected variables of Sri Lanka

\begin{tabular}{cccc}
\hline LKA & t-value & Significance & Model \\
\hline $\begin{array}{c}\mathrm{Co}_{2} \\
\text { Energy } \\
\text { Intensity }\end{array}$ & -4.102 & 0.020 & $\left(\ddot{\mathrm{A}} \mathrm{y}_{\mathrm{t}}=\mathrm{a}+\mathrm{y}_{\mathrm{t}-1}+\mathrm{T}+\mathrm{e}_{\mathrm{t}}\right) I \sim(0)$ \\
$\begin{array}{c}\text { Log of GDP } \\
\text { Renewable }\end{array}$ & -3.509 & 0.001 & $\left(\ddot{\mathrm{A}} \mathrm{y}_{\mathrm{t}}=\mathrm{y}_{\mathrm{t}-1}+\mathrm{e}_{\mathrm{t}}\right) \sim \sim(0)$ \\
$\begin{array}{c}\text { Electricity } \\
\text { Renewable } \\
\text { Energy }\end{array}$ & -2.318 & 0.011 & $\left(\ddot{\mathrm{A}} \mathrm{y}_{\mathrm{t}}=\mathrm{a}+\mathrm{y}_{\mathrm{t}-1}+\mathrm{e}_{\mathrm{t}}\right) \sim \sim(1)$ \\
\hline
\end{tabular}


Table 6. Stationary test for selected variables of Pakistan

\begin{tabular}{|c|c|c|c|}
\hline PAK & t-value & Significance & Model \\
\hline $\mathrm{CO}_{2}$ & -2.789 & 0.007 & $\left(\ddot{A} y_{t}=y_{t-1}+e_{t}\right) I \sim(1)$ \\
\hline Energy Intensity & -4.218 & 0.000 & $\left(\ddot{A} y_{t}=y_{t-1}+e_{t}\right) \mid \sim(1)$ \\
\hline Log of GDP & -3.441 & 0.021 & $\left(\ddot{A} y_{t}=a ́+y_{t-1}+e_{t}\right) \mid \sim(1)$ \\
\hline $\begin{array}{l}\text { Renewable } \\
\text { Electricity }\end{array}$ & -4.887 & 0.000 & $\left(\ddot{A} y_{t}=y_{t-1}+e_{t}\right) \mid \sim(1)$ \\
\hline $\begin{array}{l}\text { Renewable } \\
\text { Energy }\end{array}$ & -2.825 & 0.007 & $\left(\ddot{A} y_{t}=y_{t-1}+e_{t}\right) \mid \sim(0)$ \\
\hline
\end{tabular}

Source: World Development Data Base. Values are computed by researcher. Note: I (0) means integrated order of zero; the variable stationary at level data. I (1) means integrated order of one; the variable stationary at first difference data.

\subsection{Trends in Data}

In the following section, data used for the analysis have been presented in the form of figures in order to capture their trends and direction.

GDP trends in South Asia are presented in figure-1. GDP data have shown positive trend for all the countries and it is quite high for India.

Energy Intensity trends in South Asia are presented in Figure 2. Energy intensity data have shown negative trend for all the countries. Energy intensity is between two and four units during 2012 except Nepal.

Trends in renewable electricity (as share in total electricity production) in South Asia presented are in Figure 3. Renewable electricity data have shown negative trend for all the countries except Nepal.

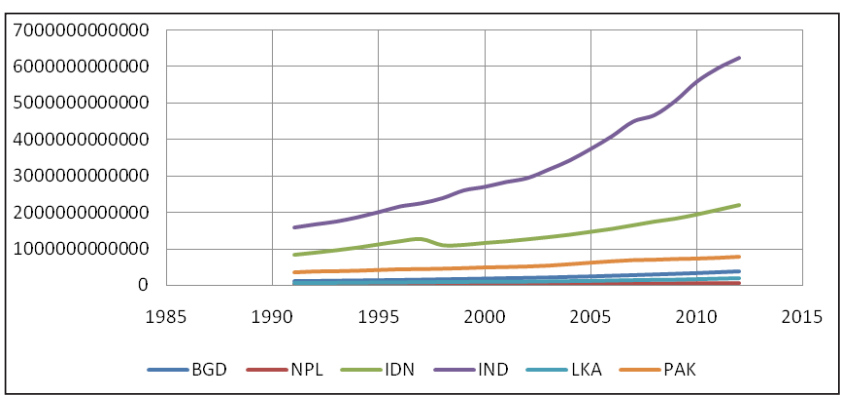

Figure 1. GDP in South Asia.

Source: World Development Data Base.
Trends in renewable energy (as share in total energy) in South Asia are presented in Figure 4. Renewable energy data have shown negative trend for all the countries.

Trends in Co2 in South Asia presented in Figure 5. Co2 data have shown negative trend for Indonesia, positive trend for Pakistan and Bangladesh and it was all most constant for Nepal, Sri Lanka and India.

\subsection{Analysis of Results}

It is noted in the methodology that, the econometric models have been constructed and measured the impact

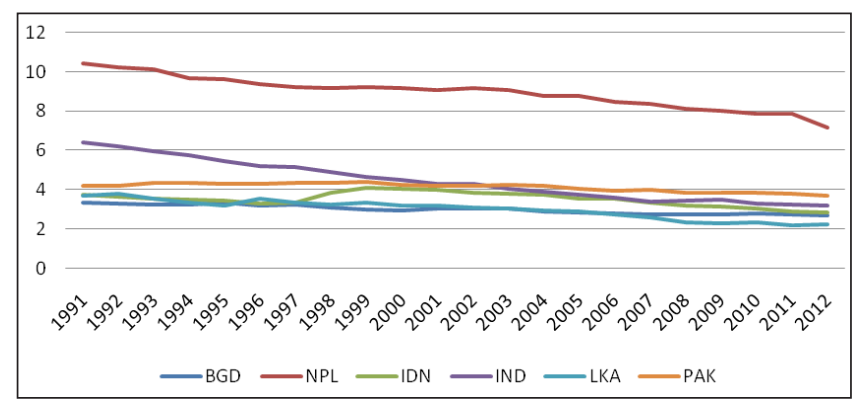

Figure 2. Energy intensity in South Asia. Source: World Development Data Base.

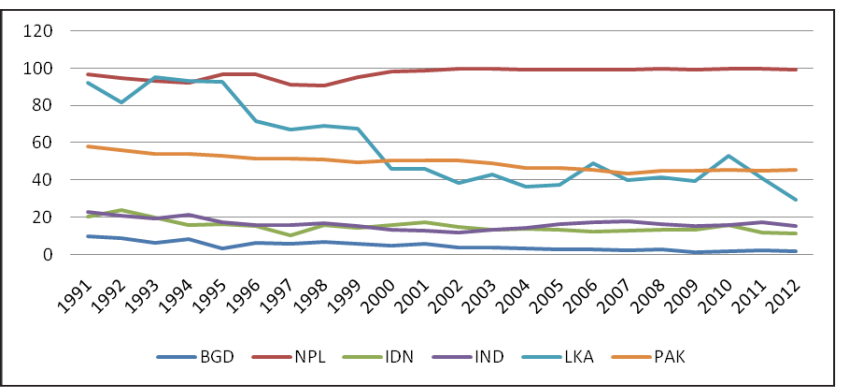

Figure 3. Renewable electricity in South Asia. Source: World Development Data Base.

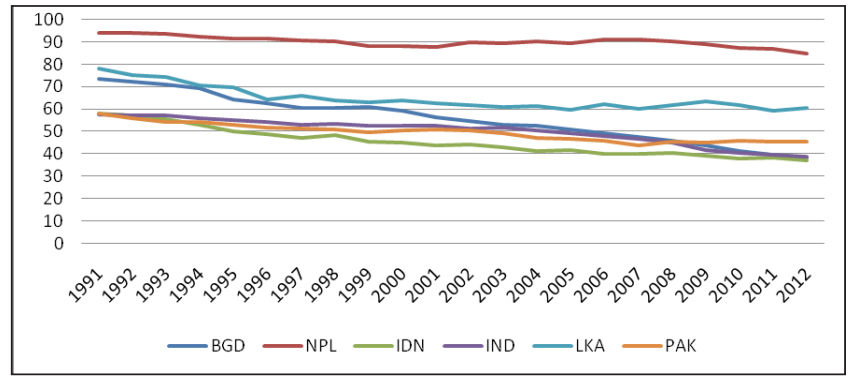

Figure 4. Renewable energy in South Asia. Source: World Development Data Base.

SDMIMD Journal of Management | Print ISSN: 0976-0652 | Online ISSN: 2320-7906 


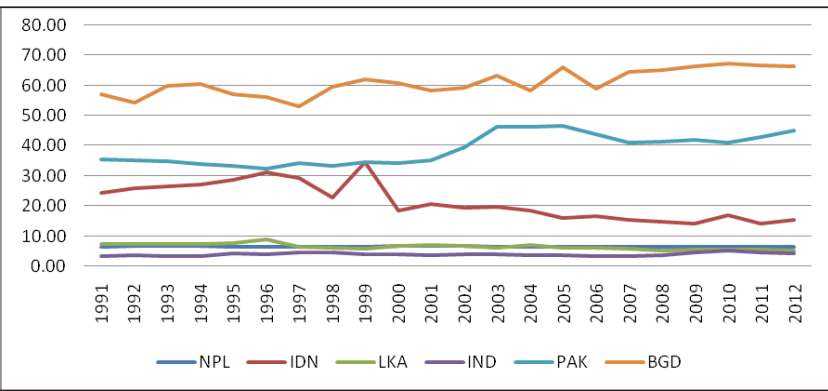

Figure 5. Co2 in South Asia.

Source: World Development Data Base.

of sustainable green and clean energy efficiency on development for each of South Asian country selected for analysis. The models, results of the models and their interpretation have been presented in the models:

The Model 1 presents information for Indonesia. It has been found from the Model 1, that the model is highly good fitted with R-squared and adjusted R-squared values. Since the DW test values are around 2 and above the R-squared value there are no autocorrelation and non-stationarity problem. Hence, the results are not spurious. The constant value is positive but not significant at five percent level. Means, if there is no contribution from the independent variables, there will not be consistent GDP in Indonesia. The F - value is highly significant. Therefore, the total variability of sustainable green and clean energy efficiency has significantly explained the variability in GDP. The t-value explains individual impact of each independent variable on dependent variable. It has been found from the beta coefficients that there is negative impact of EI on marginal change of GDP; and this is significant at one percent level. There is positive impact of REL on marginal change of GDP; but this is not significant even at five percent level. There is negative impact of RE

Model 1. Impact of sustainable green and clean energy efficiency on development in Indonesia (IDN)

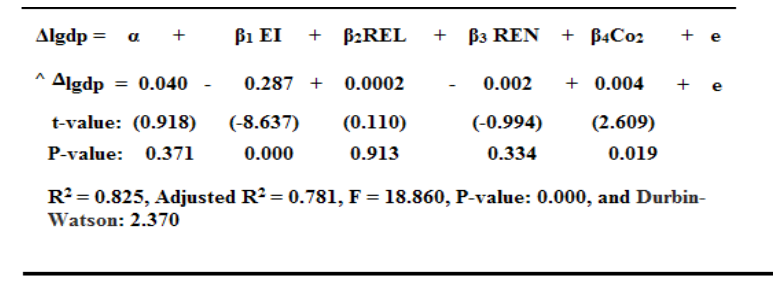

http://www.informaticsjournals.com/index.php/sdmimd | Vol 8 | Issue 1 | March 2017 on marginal change of GDP; and this is not significant even at five percent level. There is positive impact of $\mathrm{Co}_{2}$ on marginal change of GDP; and this is significant at five percent level.

Therefore, renewable energy and electricity have not significantly influenced the change in GDP of Indonesia. Accordingly, the change in GDP is not clean and sustained. The energy intensity has significantly influenced the GDP of Indonesia. Accordingly, as energy intensity decreased the GDP of Indonesia has been positively changed. The contribution of $\mathrm{Co}_{2}$ to GDP is positively significant. Accordingly, there is negative threat to the green growth of GDP of Indonesia.

Hence, the GDP of Indonesia is not based on sustained, clean and green energy.

The Model 2 presents information for Bangladesh. This model is highly good fitted with R-squared and adjusted R-squared values. Since the DW test values are around 2 and above the $\mathrm{R}$-squared value, there is no autocorrelation and non-stationarity problem as well. Hence, the results are not spurious. The constant value is positive and significant at one percent level. The $\mathrm{F}$ - value is highly significant. Therefore, the total variability of sustainable green and clean energy efficiency has significantly explained the variability in GDP. The t-value explains individual impact of each independent variable on dependent variable. It has been found from the beta coefficients that, there is negative impact of EI on marginal change of GDP; and this is significant at five percent level. There is a negative impact of REL on marginal change of GDP; and this is not significant even at five percent level. There is positive impact of REN on marginal change of GDP; and this is not significant even at five percent level. There is negative

Model 2. Impact of sustainable green and clean energy efficiency on development in Bangladesh (BGD)

\begin{tabular}{|c|c|c|c|c|c|c|}
\hline$\Delta$ lgdp $=$ & $\alpha$ & + & $\boldsymbol{\beta}_{\mathbf{1}} \mathbf{E I}+$ & $\beta_{2}$ REL + & $\beta_{3} \mathrm{REN}+$ & $\mathrm{\beta}_{4} \mathrm{Co}_{2}+\mathrm{e}$ \\
\hline$\wedge \Delta_{\text {dlgdp }}=$ & 0.205 & - & $0.033-$ & $0.0008+$ & 5.890 & $0.0007+\mathrm{e}$ \\
\hline$t$-value: & (4.439) & & $(-2.496)$ & $(-0.909)$ & $(0.018)$ & $(-2.154)$ \\
\hline P-value: & 0.0004 & & 0.0239 & 0.376 & 0.985 & 0.0468 \\
\hline \multicolumn{7}{|c|}{$\begin{array}{l}R^{2}=0.748, \text { Adjusted } R^{2}=0.685, F=11.91857, P \text {-value: } 0.0001 \text {, and Durbin-Watson: } \\
2.067518\end{array}$} \\
\hline
\end{tabular}

SDMIMD Journal of Management | Print ISSN: 0976-0652 | Online ISSN: 2320-7906 
impact of $\mathrm{Co}_{2}$ on marginal change of GDP; and this is significant at five percent level.

Therefore, REL and REN have not significantly influenced the change in GDP in Bangladesh. Accordingly, the change in GDP is not clean and sustained. The energy intensity has significantly influenced the GDP in Bangladesh. Accordingly, as energy intensity decreased the GDP in Bangladesh has been increased. The contribution of $\mathrm{Co}_{2}$ to GDP is negatively significant. Accordingly, growth of GDP in Bangladesh has been becoming green.

Hence, the GDP in Bangladesh is not based on sustained and clean energy.

The Model 3 presents information for India. This model is good fitted with low R-squared and adjusted R-squared values. Since the DW test values are around two and above the R-squared value, there is no autocorrelation and non-stationarity problem. Hence, the results are not spurious. The constant value is positive but not significant at five percent level. Means, if there is no contribution from the independent variables, there will not be consistent GDP in India. The F - value is not significant. Therefore, the total variability of sustainable green and clean energy efficiency has not been significantly explained the variability in GDP. The $\mathrm{t}$-value explains individual impact of each independent variable on dependent variable. It has been found from the beta coefficients that, none of the independent variable significantly influenced the growth GDP in India.

Hence, the GDP in India is not only inconsistent it is also not based on sustained, clean, green and efficient energy.

The Model 4 presents impact results for Sri Lanka. This model is highly good fitted with low R-squared and

Model 3. Impact of sustainable green and clean energy efficiency on development in India (IND)

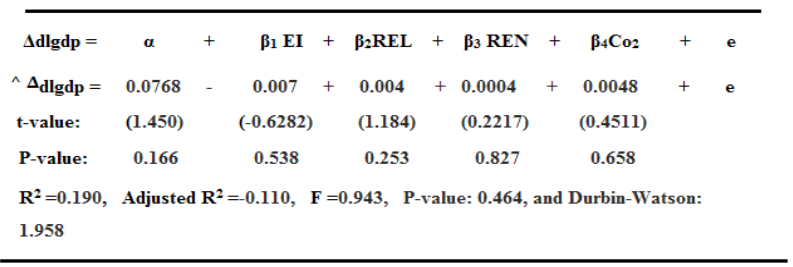

adjusted R-squared values. Since the DW test values are around two and above the R-squared value. There is there is no autocorrelation and non-stationarity problem. Hence, the results are not spurious. The constant value is positive but not significant at five percent level. It means, if there is no contribution from the independent variables, there will not be consistent GDP in Sri Lanka. The F - value is not significant. Therefore, the total variability of sustainable green and clean energy efficiency has not been significantly explained the variability in GDP. The t-value explains individual impact of each independent variable on dependent variable. It has been found from the beta coefficients that, none of the independent variable significantly influenced the growth GDP in Sri Lanka.

Hence, the GDP in Sri Lanka is not only inconsistent, but also not based on sustained, clean, green and efficient energy.

The Model 5 presents impact results for Pakistan. This model is fitted with low R-squared and adjusted R-squared values. Since the DW test values are around two and above the R-squared value, there is no autocorrelation and non-stationarity problem. Hence, the results are not spurious. The constant value is positive but not significant at five percent level. It means that, if there is no contribution from the independent variables, there will not be consistent GDP in Pakistan. The $\mathrm{F}$ - value is not significant. Therefore, the total variabil-

Model 4. Impact of sustainable green and clean energy efficiency on development in Sri Lanka (LKA)

\begin{tabular}{|c|c|c|c|c|c|c|c|}
\hline$\Delta$ dlgdp $=$ & $\alpha$ & $+\beta_{1} \mathrm{EI}$ & $+\beta_{2} R E L$ & $+\beta_{3}$ REN & $+\beta_{4} \mathrm{Co}_{2}$ & + & e \\
\hline${ }^{\wedge} \Delta_{\text {dlgdp }}=$ & 0.154 & - 0.018 & $+\quad 0.0005$ & 0.0005 & 0.007 & + & $\mathrm{e}$ \\
\hline t-value: & (1.428) & $(-1.134)$ & (1.297) & $(-0.259)$ & $(-0.8979)$ & & \\
\hline P-value: & 0.172 & 0.273 & 0.213 & 0.798 & 0.382 & & \\
\hline
\end{tabular}

Model 5. Impact of sustainable green and clean energy efficiency on development in Pakistan (PAK)

\begin{tabular}{|c|c|c|c|c|c|c|}
\hline$\Delta$ dlgdp $=$ & $\alpha+$ & $\beta_{1} \mathrm{EI}+$ & $\beta_{2} \mathrm{REL}$ & $+\beta_{3} \operatorname{REN}$ & $\beta_{4} \mathrm{C}_{02}$ & + \\
\hline $\begin{array}{l}{ }^{\wedge} \Delta_{\text {dlgdp }}= \\
\text { t-value: }\end{array}$ & $\begin{array}{l}-0.005- \\
(-0.080)\end{array}$ & $\begin{array}{c}0.104 \\
(-1.762)\end{array}$ & $\begin{array}{c}0.0007 \\
(-0.505)\end{array}$ & $\begin{array}{r}0.0008 \\
(0.652)\end{array}$ & $\begin{array}{c}-0.0005 \\
(-0.2350)\end{array}$ & + \\
\hline P-value: & 0.937 & 0.097 & 0.620 & 0.523 & 0.817 & \\
\hline $\begin{array}{l}\mathrm{R}^{2}=0.180, \\
1.102\end{array}$ & Adjusted $\mathrm{F}$ & $R^{2}=-0.023$ & $F=0.883$, & P-value: 0.495 & 5 , and Durbin- & Watson: \\
\hline
\end{tabular}

SDMIMD Journal of Management | Print ISSN: 0976-0652 | Online ISSN: 2320-7906 
ity of sustainable green and clean energy efficiency has not been significantly explained the variability in GDP. The t-value explains individual impact of each independent variable on dependent variable. It has been found from the beta coefficients that, none of the independent variable significantly influenced the growth GDP in Pakistan.

Hence, the GDP in Pakistan is not only inconsistent it is also not based on sustained, clean, green and efficient energy.

The model 6, presents impact results for Nepal. This model is highly good fitted with R-squared and adjusted R-squared values. Since the DW test value is more than one and above the R-squared value, there is no autocorrelation and non-stationarity problem as well. Hence, the results are not spurious. The constant value is negative but not significant even at five percent level. It means that, if there is no contribution from the independent variables, there will not be consistent GDP in Nepal. The F - value is not significant. Therefore, the total variability of sustainable green and clean energy efficiency has not significantly explained the variability in GDP. The t-value explains individual impact of each independent variable on dependent variable. It has been found from the beta coefficients that, there is positive impact of EI on marginal change of GDP; and this is not significant at five percent level. There is a negative impact of REL on marginal change of GDP; and this is not significant even at five percent level. There is negative impact of REN on marginal change of GDP; and this is significant at five percent level. There is positive impact of $\mathrm{Co}_{2}$ on marginal change of GDP; and this is not significant even at five percent level.

Therefore, EI, REL and $\mathrm{Co}_{2}$ have not significantly influenced the change in GDP in Nepal. Accordingly, the change in GDP is not efficient, clean and green.

Model 6. Impact of sustainable green and clean energy efficiency on development in Nepal (NPL)

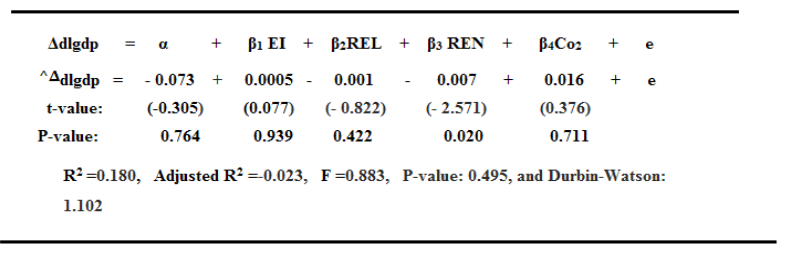

Hence, the GDP in Nepal is not based on efficient, clean and green energy. At the same time, use of renewable energy is not supporting the GDP of Nepal. Therefore, there is a serious drawback in renewable energy policy which needs to be changed.

\section{Conclusion}

The present study examined the impact of efficient clean sustained green energy on development. The model drastically failed to explain the relationship between efficient clean sustained green energy and economic development particularly in India, Sri Lanka, and Pakistan and even in Nepal. The GDP growth in these countries is not efficient, not clean, not sustained and not green. Therefore, there are serious drawbacks in energy policies of these countries which need to be addressed urgently.

In these four countries, the energy efficiency has not significantly increased in order to reduce the energy intensity in production and increase the GDP. It clearly indicates that the use of energy efficient technologies have not been advanced in these countries. Therefore, there is need for these countries to advance the technology not only in energy sector but also in all production processes.

The use of renewable electricity for production has not been significantly materialized in these countries and as a result, renewable electricity has failed to influence the GDPs of these countries. The electricity produced by renewable sources has largely been used in domestic sector and it has to be used in the production sector.

These countries have been largely used renewable energy sources. But, they are not in accordance with the need of GDP growth. The use of renewable energy has drastically failed to influence the GDP of these countries. Therefore, in order to sustain the growth, there is a need to use the renewable energy sources appropriately and judiciously, so that they should positively influence GDP.

Emission of $\mathrm{Co}_{2}$ is a major threat to the environment and it has multiple and multi-dimensional negative 
implications on the whole system. There is urgent need to reduce the $\mathrm{Co}_{2}$ emission in all these countries to make their growth green.

The things are better in Bangladesh and Indonesia. But they too have similar problems, which are of serious concerns of the policy makers. Therefore, the present study has sufficient evidences to advocate for redesigning energy policy in all these countries to make the GDP growth clean, sustained, green and energy efficient.

\section{References}

Asafu-Adjaye. (2000). The relationship between energy consumption, energy prices, and economic growth: time series evidence from Asian developing countries. Energy Economics, 22 , 615-625. Retrieved from: https://doi. org/10.1016/S0140-9883(00)00050-5

Asafu-Adjaye, J. (2000). The relationship between energy consumption, energy prices, and economic growth: time series evidence from Asian developing countries. Energy Economics, 22 , 615-625. Retrieved from: https://doi. org/10.1016/S0140-9883(00)00050-5

Baldwin, D. A. (1997). The Concept of Energy Security. Rev. Int. Stud. 23 , 5-26.Retrieved from: https://doi. org/10.1017/S0260210597000053

Bohi, D., \& Toman, M. A. (1996). The Economics of Energy Security. Norwell, Massachusetts: Kluwer Academic Publishers. Retrieved from: https://doi.org/10.1007/97894-009-1808-5

Cheng, B. (1995). An investigation of cointegration and causality between energy consumption and economic growth. Journal of Energy Development, 21, 73-84.

Glasure, Y. L. (1997). Cointegration,error correction and the relationship between GDP and energy: the case of South Korea and Singapore. Resource and Energy Economics, 20, 17-25. Retrieved from: https://doi.org/10.1016/ S0928-7655(96)00016-4

Hancock, K., \& Vivoda, V. (2014). International Political Eeconomy: A Feld Born of the OPEC Crisis Returns to its Energy Roots. Energy Research. Social Science, 1, 206-216. Retrieved from: https://doi.org/10.1016/j. erss.2014.03.017

Hansen, B. S. (2002). Testing for two-regime threshold cointegration in vector error-correction models. Journal Of Econometrics 110, 293-318. Retrieved from: https:// doi.org/10.1016/S0304-4076(02)00097-0

Huang, B. H. (2008). Causal relationship between energy consumption and GDP growth revisited: a dynamic panel data approach. Ecological Economics, 67, 41-54. Retrieved from:https://doi.org/10.1016/j.ecolecon.2007.11.006

Ito, K., Zhidong, L., \& Komiyama, R. (2005). Asian Energy Outlook up to 2020. Economic and Political Weekly September 3, 3953-3959.

Jeffrey, K., \& Hironobu, U. (2015 ). A policy-oriented approach to energy security. Procedia Environmental Sciences 28, 27-36.

Jumbe, C. (2004). Cointegration and causality between electricity consumption and GDP: empirical evidence from Malawi. Energy Economics, 26, 61-68. Retrieved from: https://doi.org/10.1016/S0140-9883(03)00058-6

Kamonphorn, K., \& Hironobu, U. (2014). ASEAN Energy Security: An Indicator based Assessment. Energy Procedia, 56, 163-171. Retrieved from: https://doi. org/10.1016/j.egypro.2014.07.145

Kokichi Ito, L. Z., \& Komiyama, R. (2005). Asian Energy Outlook up to 2020. Economic and Political Weekly XLI (16), 3953-3959.

Kraft, J. K. (1978). On the relationship between energy and GNP. Energy Development, 3, 401-403.

Lin, B. (2003). Structural change, efficiency improvement and electricity demand forecasting (In Chinese), Economic Research, 5, 57-65.

Lixia, Y., \& Youngho, C. (2014). Energy Security in China; A Quantitative Analysis and Policy Implications. Energy Policy, 67, 595-604.Retrieved from: https://doi. org/10.1016/j.enpol.2013.12.047

Lubell, H. (1961). Security of Supply and Energy Policy in Western Europe. World Polit, 13(3), 400-422. https://doi. org/10.2307/2009482

Masih, A. M. (1996). Energy consumption, real income and temporal causality: results from a multi-country study based on cointegration and error-correction modelling techniques. Energy Economics, 165-183. https://doi. org/10.1016/0140-9883(96)00009-6

Masih, A. M., Masih, A. M. M., Masih, R., (1996). Energy consumption, real income and temporal causality: Results from a multi-country study based on cointegration and errorcorrection modelling techniques. Energy Economics, 18, 165-183. https://doi.org/10.1016/0140-9883(96)00009-6

Mozumdar, P. (2007). Causality relationship between electricity consumption and GDP in Bangladesh. Energy Policy, 35(1), 395-402. Retrieved from: https://doi. org/10.1016/j.enpol.2005.11.033

Nachane, D. R. (1988). Cointegration and causality testing of the energy-GDP relationship: a cross country study. Applied Economics, 20, 1511-1531. Retrieved from: https://doi.org/10.1080/00036848800000083 
Premakumara, G. (2012). Power sector Restructuring and Reforms: From Government Failure to Market Failure. Germany: LAP.

Rahu, 1. P. (2006). How Can India Achieve Energy Security? Economic and Political Weekly, 303-306.

Sadorsky, P. (2010). The impact of financial development on energy consumption in emerging economies. Energy Policy, 38, 2528-2535. Retrieved from: https://doi. org/10.1016/j.enpol.2009.12.048

Sascha, R., \& Andreas, L. (2015). Invention in Energy Technologies: Comparing Energy Efficiency and Renewable Energy Inventions at the Firm Level. EnergyPolicy (83), 206-217.

Shahbaz, M. L. (2012). Does financial development increase energy consumption? The role of industrialization and urbanization in Tunisia. Energy Policy, 40, 473-479. https://doi.org/10.1016/j.enpol.2011.10.050

shahbaz, M. L. (2013). Natural gas consumption and economic growth in Pakistan. Renewable and Sustainable Energy Reviews, 87-94. Retrieved from: https://doi. org/10.1016/j.rser.2012.09.029

Soytas, U. S. (2003). Energy consumption and GDP: causality relationship in G7 countries and emerging markets. Energy Economics, 25, 33-37. Retrieved from: https:// doi.org/10.1016/S0140-9883(02)00009-9
Sreenivas, A. (2014). India's energy policy future: here be dragons. Future, 56, 53-61. Retrieved from: https://doi. org/10.1016/j.futures.2013.10.009

Tamizan,A.C.(2009). Doeshighereconomicandfinancialdevelopment lead to environmental degradation: evidence from BRIC countries. Energy Policy,37(1), 246-253. Retrieved from: https://doi.org/10.1016/j.enpol.2008.08.025

Thoma, M. (2004). Electrical energy usage over the business cycle. Energy Economics, 26 , 463-485. Retrieved from: https://doi.org/10.1016/j.eneco.2004.04.006

Wikipedia. (2010, December). https://en.wikipedia.org. Retrieved September 2, 2015, from Google: https:// en.wikipedia.org/wiki/Energy_security

Yoo, S. (2005). Electricity consumption and economic growth: evidence from Korea. Energy Policy. 33, 1627-1632. Retrieved from: https://doi.org/10.1016/j. enpol.2004.02.002

Yu, E. J. (1992). Cointegration tests of energy consumption, income and employment. Resource and Energy, 14(3), 259-266. Retrieved from: https://doi.org/10.1016/01650572(92)90010-E

Yu, E. (1984). The relationship between energy and GNP. Further results. Energy Economics, 6, 186-190. Retrieved from: https://doi.org/10.1016/0140-9883(84)90015-X 
